\title{
Role of Entrepreneurship and Small Business in National Development
}

\author{
Bir Bahadur Karki
}

"If you're not an owner, It's not your business"

Kay koplovit

\begin{abstract}
Entrepreneurship and small business play vital role in national development for both types of countries i.e. developed and developing countries like Nepal. Without having entreptreneurship. Goverment is not able to develop country itself. Most of the Nepalese people do not have ideas and skills about entrepreneurship and entrepreneur. Although, they have been trying to etablish as well as operate cottage and small businenes all over Nepal. Special focus has been given on Central and Eastern Development Region. Data shows that most of the Nepalese people are not economically active still now. Therefore, Government should be able to address to that types of issues and should also be able to arrange in trastructure as well as supporting programmes to those types of peoples who have entrepreneurship ideas.
\end{abstract}

Key words: entrepreneurship, cottage and small busines, national development.

\section{Introduction}

Nepal is not only a least developed country, but also one of the richest countries in terms of natural resources like hydropower, forestry \& herbal, culture, mountain, water resource in the world. But, due to the lack of entrepreneurship as well as entrepreneurs people, Nepal is known as one of the poorest countries in the world. Insufficient of capital or fund and out dated technologyes are not only barriers for national development. We can develop our nations if we have entrepreneurship. It plays vital role in national development. Through entrepreneurship, we can develop new products, enter into new market segment, generate employment opportunities and revenue, utilize natural and local resources . Due to the lack of positive attitudes and commitment towards business, we are not actually able involved in entrepreneurship and in busines. Therefore, we should have knowledge and information about entrepreneurship or entrepreneurs as well as about small business or business.

A Brief View of Global Economy: In 2006, the global economy expanded by 5.4 percent as against the rise of 4.9 percent in 2005. In 2006, the growth rate of developing Asia (including china, India and ASEAN-4) was 9.4 percent and that of emerging Asia (developing Asia and newly industrialized Asian economies) 8.9 percent. Among developing Asian economies the economic growth rate of ASEAN-4 was 5.4 percent and that of South Asia 8.7 percent. Among the high growing emerging Asian economies the growth rate of China, India and Singapore in 2006, were 10.7 percent, 9.2 percent, and 7.9 percent respectively. Like wise, in 2006, the economic growth rate of SAARC countries were as follows: Afghanistan, 8 percent, Bangladesh 6.7, percent, Bhutan 13.7 percent, India 9.2 percent, Maldives 16.1 percent, Nepal 1.9 percent, Pakistan 6.2 percent and Srilanka 7.5 percent. Among SAARC countries, the econimic growth rate of Nepal was very low. (Economy Survey: 2007)

A Brief Overview of Nepales Economy: Nepal is one of the least develop countries of 
the world. Among 23.1 million people of the country as per the census of 2001, 85.80 percent people live in the rural areas. (CBS: 2005) The preliminary estimate of per capital GDP at current prices stand at N Rs. 27,209 (US\$ 383) for the fiscal year 2006/07. The annual growth rate of GDP at producers prices is 2.50 percent in the year 2006/07. Nearly one third of the population (31.8\%) live below poverty line as per Nepal living stanard survey 2003/04 and the Ginni Coeltticient, which indicates inequality between the poor and rich is 41.4 (CBS : 2007)

A review of the share of the major production sector in GDP at real price in F. 2006/ 07 testifies to the growing predominance of the service sector in the economy. Viewed sector-wise, agriculture stands with 36.1 percent contribution to the GDP at real prices in FY 2006/07, likewise wholesale and retail trade with 13.1 percent, transport, communication and storage with 8.7 percent, industry with 7.8 percent real-state and professional services with 7.5 percent, construction with 6.1 percent and education with $5.9 \%$. The increase in service sector's contribution reflects the changing feature of economic development. Compared to its growth rate of 4.7 percent in F.Y. 2005/06, it has recorded a Phenomenal growth rate of 9.0 percent in the following year, thus increasing its total share in GDP from 46.4 percent last year to 47.1 percent this year. (Economy survey: 2007)

\section{Entrepreneurship and Entrepreneurs}

What is entrepreneurship? Simply, entrepreneurship is the process of new venture. It begins with an innovative idea. It identifies opportunities. And, who is entrepreneur? Who performs the function of entrepreneurship? Entrepreneurs launch new venture. Entrepreneurs refer those types of individuals who have innovative and creative mind as well as enthusiasic nature They possess various types of qualities such as creative and innovative mind, hard working, optimistic, positive attitudes, foresight, work independently, risk bearer, , good manager and They have vision and capability to create new ventures. rare able to able to identify new business opportunity and take advantage from it. They are achievement oriented as well as action oriented individuals driver to seek new challenges and achievement Positive and Negative Aspects of Entrepreneurship: Entrepreneurship provides opportunities for entrepreneur. It helps to the formation of capital. It is most essential for business success. It facilitates to create employment opportunities not only for owners and their relatives members, but also for other people. It helps to increase productivity. We can produce more output through using at least time, effort and at minimum resources. It also helps to balance development of the nations. Through it, national revenue can be distributed equally to all people. It has also some negative aspects such as risk of failure, emotion stress due to the changes in government policies, lack of professional manager. However, positive aspests of entreprencurship is more than negative aspects. To gain something, we should need to take some risks.

\section{Small Business/Industry}

Meaning or definition of small business differs with developed countries and developing countires. In developed country, it is defined on the basis of number of workers employed in the business In such countries, small business is that type of business which has less than one hundred workers. But in developing countries like Nepal, it is defined on the basis of fixed capital investment. It means, in such countries, small business is that type of business which has invested less than Rs. 30 million fixed capital on business, Small 
business possesses distinct features such as independent management, closely held ownership, local operation, small size limited resources etc. Most of the owners of small business perform managerial functions by themselves. If they arrange or recruit other people in managerial activities, they establish close relationship with them.

At the initial stage of business life cycle, most of the businesses are established in the form of small business. Generally, entrepreneurs are involved to establish small business or new venture.

\section{Problems \& challenges}

Nepal confronts with a number of economic challenges at present : low economic growth, low per capita income, higher level of poverty, poor social indicator, under developed physical intrastructure, and high cost economy leading to higher cost of production and so on while the world economy in general and the emerging and developing economics. India and china at our doorsteps, in particular, are moving fast along the trajectory of economic growth. Nepal still finds itself grappled with a host of problems that demand early and effective solutions to ensure an inclusive, just and high economic growth on a sustainable basis.

\section{Objective of the study}

The main objective of the study is to highlight the major contribution of small businenes and entreprencurship in the context of national development of Nepal. Other objectives of the study are as follows:-

1. To identify what types of contribution made by the small business in the contest of national development

2. To explore the role of entrepreneurship in the development of small business

\section{Significance of the study}

The study tries to highlight the role of entrepreneurship and small business for national development. Besides it, the study will try to provide some basic knowledge of the entrepreneurship and small business. The study also helps to gain some information about it to student, researchers, businessmen and other ordinary people.

\section{Methodology}

The study is based on descriptive research design. Data are collected mainly from secondary sources. Data are gathered from reports, annual progress reports, journals and other publication. Specially, data are collected from publication of Government of Nepal. Limitation of the study :- Due to lack of new industrial ccnsus, latest data are not able included in it. Because, Government of Nepal is going to conducting census of industrial sector in the current year. Data are presented in tables. To analyze data, only one tools i.e. percentage is used.

\section{An overview of Contribution of Small Business and Entrepreneurship}

Small business is the driver of economy in almost all countries. Most of the businesses are small. They are growing rapidly. It is easy to establish. Therefore, it attracts to people of all ages and all types of discipline. Compared with large business, the relative importances of small business are as follows: -

Encourage Innovation and Entrepreneurship: Entrepreneur are know as hard workers, risk bearers, foresighters, organizers and good leaders. They have always been given em- 
phasized on innovation. One study (USA) found that half of all innovation and $95 \%$ of all radical innovations are made by entrepreneurs or small business firms. In another study it was found that, small business in the United States are credited with contribution about 55 percent of the new innovation and are responsible for inventions including the airplane, double knit fabric, the zipper, the pacemaker, soft contact lenses and the personal computer. Most of the new innovation and development of new products are made by the small business firms. Through innovation, an entrepreneur discovers new things, new products or services, modifies existing products, and makes goods for multipurpose. Through such innovations and activities, society is being nurtured from new products, services and facilities which are usually possessed high quality some products feature better performance and cheapest prices.

Complementary to Large Business: There is not one company which can stand itself or fully independent from all types of resourcs. Large companies need to take support from other small business firm. Small business firm supports to large companies by providing accessory items like miner tools, fabricating or spares parts. In USA, General motors procure inputs services from more than 37000 small businesses. The global industries of USA and Japan run without supplies from small business. So, small business is complementary to large business. They serve as ancillary units for them. They have backward linkage with large business to supply inputs. They have also forward linkage with large business to distribute products. They add value to the supply chain of big business. Both are interdependent on each other.

Job Creation and Satisfaction: Entrepreneurs are also known as job creators. They create jobs not only for themeselves but also for others. Small business creates more new jobs compared to large business. Over 98 percent of the businesses in USA are technically considered small. Almost one million new businesses are started each year. Between 1992 and 1998, small companies created nearly all of the 12 million net new jobs. The smallest of those, business with fewer than 20 employees, generated more than two -thirds of the new jobs. Firms with fewer than five employees generated just over half of those new jobs. Small business with fewer than 100 employees employ nearly 40 million American, and provide 67 percent of the initial jobs opportunities and on the job training. In the context of Nepal , small manufacturing establishment account for about 60 percent of industrial employment . They are largely labour-intensive. Merchandise small business are found all over the country .They Maintain close relation with customers. Small business in tourism and transport are also important source of employment. by creating jobs for others, they get satisfaction. They also get satisatifation from ownership as well as from self employment. So, we can say small business helps to solve UN employment problems of the society as well as of the nation.

Higher Financial Reward: Most of the new innovation or inventions and development of new products or services are created by the entrepreneurs and small business firms. They are able to launch and to introduce new prsducts into market. They can determine higher price on their new products and can also enjoy from higher rate of financial reward. They have possessed patent right, copyright, goodwill and high image within an industry as well as in global market. Due to low capital investment and operate in full capacity of production, small business can generate higher rate of return on investment. 
Economic Backbone: Small businesses are assumed as on important economic backbone of each and every country. They are not only involved in generating employment opportunities to people but also play a vital role to generate foreign currency through exporting goods in abroad. They help to utilize local resources, skills and techniques to produce goods and services.

Table No. 1

Cottage and Small Industries on the Basis of Classification of Firm

\begin{tabular}{|c|c|c|c|c|c|c|}
\hline First year & $\begin{array}{c}\text { Private } \\
\text { firm }\end{array}$ & $\begin{array}{c}\text { Partnership } \\
\text { Firm }\end{array}$ & $\begin{array}{c}\text { Private } \\
\text { Ltd. }\end{array}$ & Total & $\begin{array}{c}\text { Capital Investment } \\
\text { in Rs 10 Million }\end{array}$ & $\begin{array}{c}\text { No. of } \\
\text { Employmen }\end{array}$ \\
\hline $1989 / 90$ & 42,467 & 2827 & 2132 & 47,426 & 974.254 & 440940 \\
\hline $1990 / 91$ & 4822 & 273 & 108 & 5203 & 113.00 & 37095 \\
\hline $1991 / 92$ & 4968 & 465 & 242 & 5675 & 140.00 & 85125 \\
\hline $1992 / 93$ & 6087 & 398 & 296 & 6781 & 315.00 & 82176 \\
\hline $1993 / 94$ & 8535 & 630 & 321 & 9489 & 572.00 & 153, o00 \\
\hline $1994 / 95$ & 7833 & 439 & 247 & 8519 & 537.64 & 75091 \\
\hline $1995 / 96$ & 8638 & 468 & 544 & 9650 & 722.00 & 92581 \\
\hline $1996 / 97$ & 7404 & 446 & 346 & 8196 & 604.00 & 85540 \\
\hline $1997 / 98$ & 8669 & 471 & 481 & 9621 & 881.00 & 93094 \\
\hline $1998 / 99$ & 8789 & 684 & 533 & 10,006 & 962.00 & 88973 \\
\hline $1999 / 00$ & 8889 & 549 & 685 & 10,123 & 1035.00 & 76618 \\
\hline $2000 / 01$ & 8368 & 407 & 542 & 9371 & 732.00 & 67995 \\
\hline $2001 / 02$ & 8851 & 526 & 513 & 9890 & 772.00 & 67374 \\
\hline $2002 / 03$ & 6778 & 454 & 340 & 7562 & 591.00 & 47455 \\
\hline $2003 / 04$ & 5985 & 548 & 600 & 7133 & 611 & NA \\
\hline $2004 / 05$ & 6972 & 499 & 559 & 8030 & 1101 & NA \\
\hline $2005 / 06$ & 7322 & 372 & 536 & 8230 & 377 & NA \\
\hline Total & 161377 & 10456 & 9025 & 180858 & 11039.894 & 1494037 \\
\hline Percentage & $89.23 \%$ & $5.78 \%$ & $4.99 \%$ & $100 \%$ & & \\
\hline
\end{tabular}

Source : Industrial Promotion Statistics, 2060, P-19, Economic survey, 2007, $p 74$ NA : Not available

The Table No.1 shows that 180858 small business firms are able to generate employment opportunities to 1494,037 . People out of total business firms $89.23 \% 5.78 \%$ and $4.99 \%$ business firm are established by under private firm, partnership and Private Limited company actrespectively. It also refers that most of businesses are small businesses and established by an individual enterpreneurg.

Loan Investment to those persons who have got skill oriented training by department of cottage and small industry and its.

Table 2

Loan Investment to Cottage \& Small Industry -Till FY2059/ 060

\begin{tabular}{|c|c|c|c|c|}
\hline No. of Entrepreneurs & Investment & \multicolumn{3}{|c|}{ Loan Recovery } \\
\hline 1 to 75 District & & Principle & Interest & Total \\
6267 & 38720 & 10,672 & 2911 & 13583 \\
\hline
\end{tabular}

Sources: Department of Cottage\& Small Industry 2060.p-35 
Table No 3

Statement of Registeration of Cottage and Small Industry (Industry Basis.)

\begin{tabular}{|c|c|c|c|c|c|c|c|c|c|}
\hline S.N. & $\begin{array}{l}\text { Classification } \\
\text { Fiscal Indus- } \\
\text { Year (FY) try }\end{array}$ & $\begin{array}{l}\text { Producation } \\
\text { Oriented }\end{array}$ & $\begin{array}{c}\text { Energy } \\
\text { Oriented }\end{array}$ & $\begin{array}{l}\text { Agriculture } \\
\text { Forest }\end{array}$ & Mineral & Tourism & $\begin{array}{l}\text { Constr } \\
\text { uction }\end{array}$ & Service & Total \\
\hline 1. & $1996 / 97$ & 5080 & $\overline{23}$ & 81 & 23 & 246 & 632 & 2111 & 8196 \\
\hline 2. & $1997 / 98$ & 5943 & 34 & 164 & 27 & 281 & 925 & 2247 & 9621 \\
\hline 3. & $1998 / 99$ & 6351 & 282 & 91 & 35 & 343 & 727 & 2177 & 10006 \\
\hline 4. & $1899 / 2000$ & 6201 & 209 & 193 & 20 & 382 & 1040 & 2078 & 10123 \\
\hline 5. & $2000 / 01$ & 5742 & 123 & 206 & 20 & 323 & 935 & 1968 & 9317 \\
\hline 6. & $2001 / 02$ & 5927 & 75 & 263 & 31 & 342 & 495 & 2757 & 9890 \\
\hline \multirow[t]{3}{*}{7.} & $2002 / 03$ & 4583 & 60 & 201 & 19 & 213 & 310 & 2176 & 7562 \\
\hline & $\begin{array}{c}\text { Total } \\
\text { Number }\end{array}$ & 39827 & 806 & 1199 & 175 & 2130 & 5064 & 15514 & 64715 \\
\hline & $\begin{array}{l}\text { Total in } \\
\text { Percent }\end{array}$ & $61.54 \%$ & $1.24 \%$ & $1.85 \%$ & $0.27 \%$ & $3.30 \%$ & $7.83 \%$ & $23.97 \%$ & $100 \%$ \\
\hline
\end{tabular}

Sources: Industrial Promotion statistics, 2060, $P: 8$

Seven types of existing cottage and small idustries found. These industries are production-oriented, energy-oriented, agriculture and forestry-oriented, mineral, tourism, service and construction industries. It is recorded that total number of registration of cottage and small business are found 64715 from the record of fiscal year 1996/97 to 2002/03. Out of them, production-oriented industries occupied by 61.54 percent, then after service industries occupied by 23.97 percent. These seven different types of cottage and small business were registered 8196, 9621, 10006, 10123, 9317, 9890 and 7562 from fiscal year 1996/97 to fiscal year 2002/03 respectively. It seemed that number of firm registration trends have been decreasing fiscal year.

Table No 4

Statement of Registeration of Cottage and Small Industry (Regional Basis.)

\begin{tabular}{c|c|c|c|c|c|c|c|c|c|c}
\hline \multirow{2}{*}{ S.N } & Fiscal & \multicolumn{7}{|c|}{ Classification of Industry } & \multicolumn{2}{|c}{ Total } \\
\cline { 3 - 11 } & Year & $1996 / 97$ & $1997 / 98$ & $1998 / 99$ & $1899 / 2000$ & $2000 / 01$ & $2001 / 02$ & $2002 / 03$ & $\%$ & \\
\hline 1. & Eastern & 2025 & 2197 & 2325 & 2381 & 2207 & 1964 & 1418 & 22.43 & 14517 \\
2. & Central & 3589 & 3788 & 4982 & 4936 & 4242 & 4735 & 3935 & 46.68 & 30207 \\
3. & Western & 1209 & 1397 & 1432 & 1564 & 1694 & 1638 & 1231 & 13.36 & 8650 \\
4. & mid-westera & 642 & 736 & 734 & 757 & 655 & 786 & 580 & 7.56 & 4890 \\
5. & Farwesten & 695 & 1379 & 1402 & 1477 & 1457 & 744 & 385 & 9.56 & 6189 \\
6. & Department & 36 & 26 & 37 & 80 & 47 & 23 & 13 & 0.41 & 262 \\
\hline & Total & 8196 & 9621 & 10006 & 10123 & 9317 & 9890 & 7562 & 100 & 64715 \\
\hline
\end{tabular}

Sources: Industrial Promotion statistics, 2060, P:16.

Out of total cottages and small industries (from F.Y. 1996/97 to F.Y. 2002/03) 64715, the highest number of the Time i.e. 30207 (46.68\%) registred in central development region and this region covered 46.68 percent of total Time. Then after, Eastern development region, Western, Far-western and maid-western development region cover 22.43 percents 13.36 percent, 9.56 percent, and 7.56 percent respectively. In conclusion, we found that most of the cottage and small industries are registered in central development region. Therefore, Government of Nepal should for malate appropriate policies and strategies for establishment of these types of industries into other development regions. These types of policies 
and strategies should be able to formulate appropriate programmes for these regions and such programmes should be able to encourage to establishe cottage and small industries.

\section{Table No 5}

Economically Active and Not Active Population Aged 10 years and Over by Sex 2001

\begin{tabular}{|c|c|c|c|c|c|c|c|c|}
\hline \multirow{3}{*}{ Area } & \multirow{3}{*}{ Sex } & \multicolumn{7}{|c|}{ Population 10 years and Above } \\
\hline & & \multirow{2}{*}{ Total } & \multicolumn{3}{|c|}{ Usually Active } & \multirow{2}{*}{$\begin{array}{c}\text { Not Usually } \\
\text { Active }\end{array}$} & \multicolumn{2}{|c|}{ No. of Not Eco } \\
\hline & & & Employed & $\%$ & No of unemplaed & & mically Active & $\%$ \\
\hline \multirow{3}{*}{ Nepal } & $\overline{\text { le }}$ & $\overline{7}$ & $52,12,339$ & 2.56 & $4,19,384$ & $3,39,327$ & $23,59,547$ & 28.32 \\
\hline & emale & 39, & $63,89,061$ & 43.71 & $4,40,713$ & $5,36,444$ & $3,77,480$ & 44.71 \\
\hline & Both & 95 & 89,0 & 53.00 & $8,60,097$ & $8,75,771$ & 027 & 36.57 \\
\hline & Male & 14,769 & $7,68,8$ & $\overline{58.48}$ & $\overline{66,}$ & 28,855 & $4,50,987$ & 34.30 \\
\hline & nale & & 3 , & 28.03 & 67 & 55,023 & 44 & 62.00 \\
\hline \multirow[t]{2}{*}{$14.20 \%$} & Both & 16 & $11,14,798$ & 47.74 & $1,33,909$ & 83,878 & $12,16,131$ & 47.72 \\
\hline & 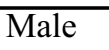 & 28 & $\overline{44,4}$ & 63.33 & 3,53, & $3,10,472$ & $19,08,560$ & 27.20 \\
\hline & Female & 05,751 & $33,43,115$ & 46.39 & $7,52,879$ & $4,81,421$ & $30,08,336$ & 41.75 \\
\hline $85.80 \%$ & oth & $1,42,21,579$ & $77,86,602$ & 54.75 & $7,26,188$ & $7,91,893$ & $49,16,896$ & 34.57 \\
\hline
\end{tabular}

Sources: Statistical year Book, 2005, P:42

On the basis of population census of Nepal, among total econimically active people 14.20 percent people and 85.80 percent people are living in urban and rural area respectively. Average economically active population is 53 percent, in which 62.56 percent is covered by male and 43.71 percent covered by female. In Comparison of urban male population with rural male population, rural population $(63.33 \%)$ is found more active than urban $(58.48 \%)$. But in the context of female population, it is slightly different. In urban area, only 28.03 percent female population is economically active, but it is almost double in rural are i.e. 46.39 percent female population is active in rural area. Government of Nepal should formulate different strategies to involve other not economically active Nepalese people for national development.

Table No 6

Economically Active and Inactive Population

\begin{tabular}{|c|c|c|c|c|c|c|c|c|c|c|}
\hline & \multicolumn{5}{|c|}{ Economically active } & \multicolumn{5}{|c|}{ Economically Inactive } \\
\hline & \multirow{2}{*}{ Total } & \multicolumn{2}{|c|}{ Male } & \multicolumn{2}{|c|}{ Female } & \multirow{2}{*}{ Total } & \multicolumn{2}{|c|}{ Male } & \multicolumn{2}{|c|}{ Female } \\
\hline & & No. & $\%$ & No. & $\%$ & & No. & $\%$ & No. & $\%$ \\
\hline & 6 & 4479944 & 65.39 & 2370942 & 34.61 & 02 & 907670 & 24.75 & 2759332 & $\overline{75.25}$ \\
\hline & & 4375583 & 59.62 & 2964003 & 40.38 & & 2043899 & 36.25 & 3594125 & 63.7 \\
\hline 2001 Census & 8901400 & 5212339 & 58.56 & 3689061 & 41.44 & 6133027 & 2359547 & 38.47 & 3773480 & 81.5 \\
\hline
\end{tabular}

Sources: Nepal District Pootile, 1999, p:12

According to population census of 1981, 1951 and 2001; economically active male poplation have been found in deereasing trend i.e. 65.39 percent, 59.62 percent and 58.56 percent in 1981, 1991, and 2001 respectively. But comparison with male population, economically active female population have been found in increasing trends i.e. 34.61 percent, 40.38 percent and 41.44 percent in 1981, 1991 and 2001 respectively. It also reveals that economically active total population is also found in decreasing trends. 


\section{Conclusion}

To ehance National economy entrpreneurship ideas and entrepreneurs are most essential. For the commencement of any types of busines people must have entrpreneurship ideas and they may start their own business inform of cottage and or small size business. Nepalers economic indicator shows that, Nepal is one of the poorest counrty in the world. Most of the people have not own business and have not got employment opportunities elswhere. Small businesses play vital role in national economic development specially developing countries. Therefore, we can not ignore the role of entrepreneurship and small business in national development. Small is beautiful. Cottage industry is known as small business. Small idustry can also be contribute in national economic development and can be made beautiful industry. It can be established easily and operated in a local level by using local resources. Most of the commodities are brought from outside countries and very few number and tyes of commodities are exported into outside country and also most of the peolpe are faced with unemploment problems. To increase producticity and to provide employment opportunities to people, government as well as Nepalese people should establish cottage and small business in all over the countey. Povery allieviation is major challeng and goal of the Government of Nepal. In this context, all Nepalese people should consider about it and should involve in national economic activities. For it, Government should need to formulate goal, strategies, policies for poverty allieviation. Without increasing productivity and efficiency, we can not able to compete with global markets.

\section{REFERENCE}

Acharya,Khagendra, (2063). Entrepreneurship and Small Business Management, Kathamandu. MK Publisher\& Distributors

Agrawal, Govindra Ram (2005). Entrepreneurship and Small Business Management in Nepal, Kathamandu: MK Publishers \& Distributors.

Broom H.N., Longnecks Justin Go, and Moore Carlos W. (1983), Small Business Management (6th Ed) Cincinnati, Ohio: South Western Publishing Co

Central Bureau of Statistics (CBS) (2003). Census of Manufacturing Establishment Nepal (CME) (20012002, National Level), Kathmandu: National Planning Commission Seeretariat (NPCS) .

CBS, (2005). Statistical Year Book of Nepal, Kathamandu: NPCS.

CBS (2006). Nepal in Figures, Kathmandu: Government of Nepal, NPCS.

CBS (2007). Nepal in Figures, Kathmandu: NPCS.

CBS (2007). Statistical Year Book of Nepal, Kathmandu: NPCS.

Charles L, Fred Stoner abed Shattuck E. Richard, (2001). Business in Integrative Approach (2nd Ed) New York: Irwin Mc Graw- Hill

Department of Cottage and Small Industry, (2064). Industrial Promotion Statistics, Kathmandu; HMG Ministry of Industry Commerce and Supply.

Holt, David H.(2004). Entrepreneurship New Venture Creation, New Delhi: Prentice Hall of India Koplovitz, Kay, (2002). Bold Big Women Ideas, New York: Public Affairs.

Longenecker, Justin, Moore Carlos W. and Petty J William (1994). Small Business Management: An Entrepreneurial Emphasis 9th Ed, Ohio: South Western Publishing Co.

Ministry of Finance (MOF) (2007). Economic Survey F.Y. 2006/07 Kathmandu: MOF, Government of Nepal.

NRA (1999). Nepal District Profile, Kathmandu: National Research Associate (NRA).

Siropolis, Nicholas zl. (1986) Small Business Management (3rd Ed) Boston: Houghton Mifflin Company. Shrestha, Juddha Bahadur (1980) Role of Entrepreneurs and Managers in Nepal. Management Dynamics Vol.1 No 1 Kathamandu: Shanker Dev Campus

Walters, Jamie (2001) Big vision, Small Business, San Franciso: IVK Sea Publishing 